\title{
EMISSIONS OF POLLUTANTS AND AIR QUALITY IN THE AREA OF INFLUENCE OF HIGH VOLTAGE OVERHEAD ELECTRICAL LINES
}

\author{
D. COCIORVA ${ }^{1}$, Mihaela Andreea MITIU ${ }^{1}$, Mariana MINCU ${ }^{1}$, Natalia \\ Simona RAISCHI
}

\begin{abstract}
Emissions of pollutants and air quality in the area of influence of high voltage overhead electrical lines. This paper presents some theoretical and experimental considerations regarding to the impact of energy fluxes that pass through the conductors of high voltage aerial electrical lines $(>110 \mathrm{kv})$ on the environment. Overhead high voltage lines generating air pollution by ozone and nitrogen oxides as a result of corona discharges occurring around active conductors, especially during humid weather. Experimental measurements performed using a test van equipped with analyzers and weather station have shown the difference regarding the concentration of pollutants (emissions) that exists in the lines of high voltage and level of the concentrations outside the area of influence of high voltage power lines.
\end{abstract}

Keywords: ozone, nitrogen oxides, corona effect, air pollution, emissions.

\section{INTRODUCTION}

During LEA operation under certain atmospheric conditions like relative humidity increased, are produced electrical discharge phenomena limited around conductors. These phenomena are determinated by the high electric field intensity generated by power line conductors. These phenomenon appear because of Corona effect, this effect can lead,in the air, toxic compounds such as nitrogen oxide and ozone. Thus, a power line can be considered a linear source of air pollution, particularly by issuing ozone and nitrogen oxides. The air is the environmental factor which is the fastest support favoring the transport of pollutants in the environment.

As Vatra (2011) affirm, emissions of pollutant substances discharged into the atmosphere and how they are dispersed requires exact knowledge of the meteorological conditions (wind speed and direction, humidity, solar radiation) and surface roughness of the ground on which are located LEA.

\section{EXPERIMENTAL MEASUREMENTS IN THE VERY HIGH VOLTAGE POWER LINES}

Monitoring of interest pollutants $\left(\mathrm{O}_{3}, \mathrm{NOx}\right)$ was performed using a test van which has in its component and analyzers to measure $\mathrm{NO}, \mathrm{NO}_{2}, \mathrm{NOx}, \mathrm{O}_{3}$ and a

\footnotetext{
${ }^{1}$ National Institute for Research \& Development in Environmental Protection, 294 Splaiul Independenţei, 6th District, 060031, Bucharest, Romania, email: dancociorva@yahoo.com
} 
weather station. Measurements were made in the area of 400/220/110 kV Brazi Vest electric station, Transelectrica, Prahova County.

Data obtained from measurements made were reported to Law no. $104 / 2011$ on ambient air quality, this Law transpose into national law the provisions of Directive 2008/50 / EC of the European Parliament and of the Council of 21 May 2008 on ambient air quality and cleaner air for Europe.

\subsection{Measurements concerning ozone concentrations}

Ozone measurements made in the area of overhead lines influence recorded a maximum value of $66.63 \mu \mathrm{g} / \mathrm{m}^{3}$ and a minimum of $3.4 \mu \mathrm{g} / \mathrm{m}^{3}$.

The maximum of ozone value was reached in daylight at a temperature of $25{ }^{0} \mathrm{C}$, relative humidity was $35 \%$, solar radiation recorded was $123.9 \mathrm{~W} / \mathrm{m}^{2}$, in atmospheric calm conditions.

The minimum of ozone value was reached at night, at a temperature of $21.2{ }^{0} \mathrm{C}$, relative humidity was $35 \%$, solar radiation recorded was $20.3 \mathrm{~W} / \mathrm{m}^{2}$, in calm atmospheric conditions.

As can be seen from the data presented above, the maximum ozone concentrations was recorded during the day, when solar radiation is much higher that in the night. Solar radiation was recorded by DPA 806 sensor.

Figure 1 show the evolution of ozone concentrations near overhead power lines, 400/220/110 kV, near Electric Station Brazi Vest.

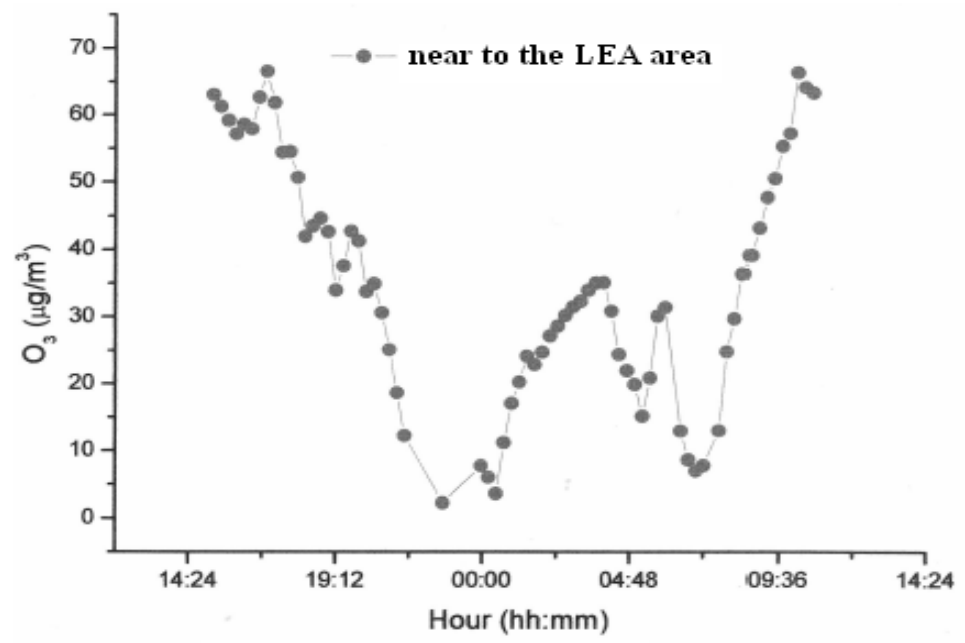

Fig. 1. Concentrations of $\mathrm{O}_{3}$ measured (LEA area), during August 2016

When measurements were made, the air temperature ranged from $25.7{ }^{\circ} \mathrm{C}$ during the day to $18.3{ }^{\circ} \mathrm{C}$ at night, humidity ranged around $25 \%$ and an average wind speed of $0.65 \mathrm{~m} / \mathrm{s}$.

These measured ozone values were compared with values stipulated in Law no. 104/2011 on ambient air quality, for alert and information thresholds. Table 1 presents the values for alert and information threshold stipulated in this Law. 
Tablel 1. Information and alert threshold for ozone, according to Law no. 104/2011 on ambient air quality*** (2011)

\begin{tabular}{|l|l|l|}
\hline \multicolumn{1}{|c|}{ Scope } & \multicolumn{1}{c|}{ Averaging period } & \multicolumn{1}{c|}{ Threshold } \\
\hline Information & one hour & $180 \mu \mathrm{g} / \mathrm{m}^{3}$ \\
\hline Alert & one hour & \\
\hline
\end{tabular}

* For the implementation of article 53 of law 104/2011, exceeding of the alert threshold is to be measured or forecasted for three hours consecutive.

The concentrations values of ozone recorded in the influence area of overhead lines, do not exceed the information threshold value provided by Law $104 / 2011, * * *(2011)$.

To see the influence of overhead power lines on the environment and to make a comparison, were made measurements of ozone concentrations and in an area where there are not overhead lines, figure 2.

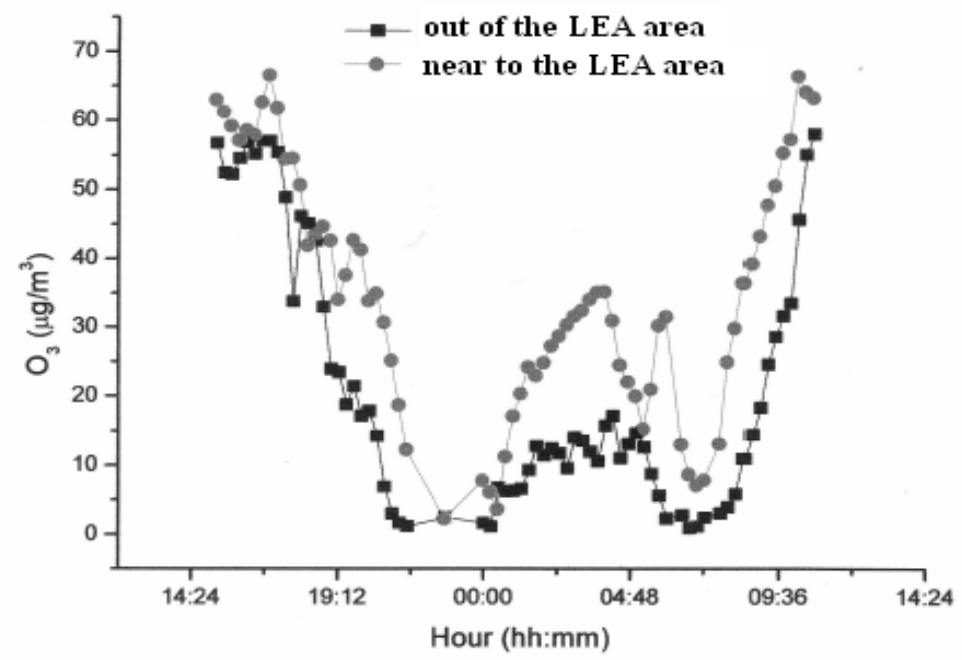

Fig. 2. Concentrations of $\mathrm{O}_{3}$ measured in different areas during August 2016

Figure 3 indicate the distance between the two locations (about $5.19 \mathrm{~km}$ ) where measurements were made for air quality parameters, in this case, ozone and nitrogen oxides.

Ozone values recorded in this area were: maximum value of $58.07 \mu \mathrm{g} / \mathrm{m} 3$, this value was recorded in daylight, at a temperature of $29{ }^{\circ} \mathrm{C}$, relative humidity was around $15.73 \%$ and wind speed recorded a value of $0.72 \mathrm{~m} / \mathrm{s}$, the minimum value was $3.02 \mu \mathrm{g} / \mathrm{m} 3$, this value was recorded at night, at a temperature of $24.4{ }^{\circ} \mathrm{C}$, relative humidity being around the $14.06 \%$ and wind speed recorded a value of $0.65 \mathrm{~m} / \mathrm{s}$.

The data presented in figures 1 and 2, demonstrate that the lowest ozone concentration at both measuring points were determinated at night, when solar radiation is small. 


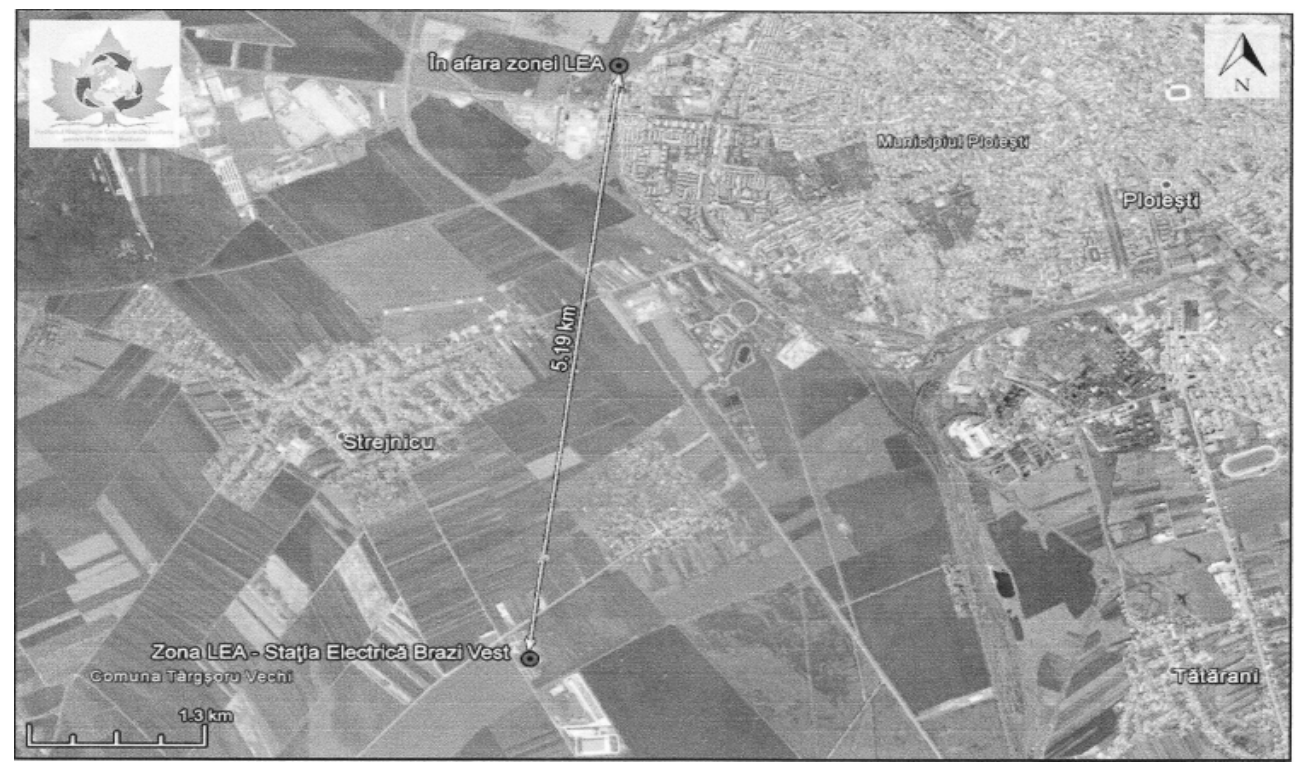

Fig. 3. Locating the two areas where measurements were made during August 2016

$\mathrm{O}_{3}$ concentrations near overhead power lines depend on meteorological parameters (especially relative humidity, wind speed and direction, solar radiation) Vaida et al (2008). During the measurements of ozone concentrations that have been made near overhead power lines were not encountered certain atmospheric conditions like increased relative humidity, favoring the phenomenon Corona, or high wind speeds, but still can be observed difference between the two areas where measurements were made.

The influence of meteorological parameters on the ozone concentration variation is discussed and it is determined that the relative humidity, wind speed and direction, solar radiation were the most important parameters causing the ozone concentration increase in the surroundings of LEA.

\subsection{Measurements concerning nitrogen oxides concentrations}

The nitrogen oxides measurements made in the area of overhead lines influence recorded a maximum of $106.68 \mu \mathrm{g} / \mathrm{m}^{3}$, this value was obtain at night at a temperature of $22.1{ }^{0} \mathrm{C}$, relative humidity of $35 \%$ wind speed recorded a value of $0.63 \mathrm{~m} / \mathrm{s}$ and a minimum value was $30.09 \mu \mathrm{g} / \mathrm{m}^{3}$, this value was recorded in daylight at a temperature of $22.7{ }^{\circ} \mathrm{C}$, relative humidity of $35 \%$ and a wind speed of $0.63 \mathrm{~m} / \mathrm{s}$.

To see the influence of overhead power lines on the environment and to make a comparison, were made measurements of nitrogen oxides concentrations and in an area where there are not overhead lines, the distance between location is $5.19 \mathrm{~km}$.

The values of nitrogen oxides recorded in this area were: maximum value of $82.1 \mu \mathrm{g} / \mathrm{m}^{3}$, this value was obtain at night at a temperature of $24.2{ }^{\circ} \mathrm{C}$, relative humidity $14 \%$, wind speed recorded a value of $0.65 \mathrm{~m} / \mathrm{s}$ and a low value of 33.25 
$\mu \mathrm{g} / \mathrm{m}^{3}$, this value was recorded in daylight at a temperature of $22,4{ }^{0} \mathrm{C}$, relative humidity $13.34 \%$ and wind speed $0.62 \mathrm{~m} / \mathrm{s}$.

Figure 4 show the evolution of nitrogen oxides concentrations, in the two areas where measurements were made with the test van.

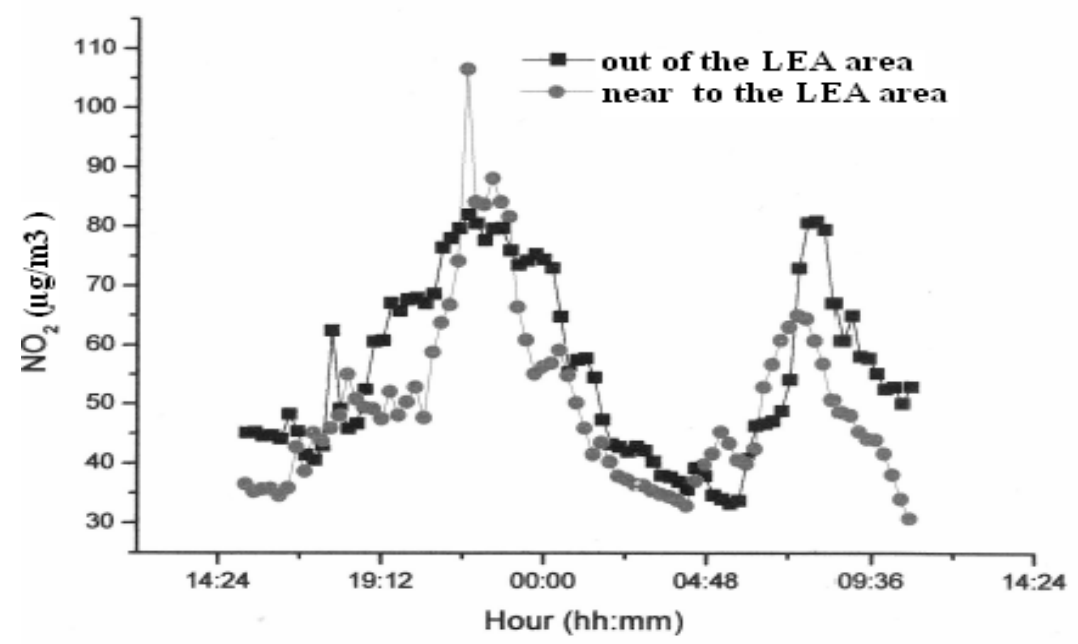

Fig.4. Concentrations of $\mathrm{NO}_{x}$ measured in different areas during August 2016

These measured values of nitrogen oxides were compared to the values stipulated in Law no. 104/2011 on ambient air quality, for the alert threshold. In Table 2 it can see the alert threshold set out in this law.

Table 2. Alert threshold and limit values for nitrogen oxides, according to Law no. 104 / 2011 on ambient air quality*** (2011)

\begin{tabular}{|l|l|}
\hline $\begin{array}{l}\text { Alert } \\
\text { threshold }\end{array}$ & $\begin{array}{l}400 \mu \mathrm{g} / \mathrm{m}^{3} \text { - measured for } 3 \text { consecutive hours at locations representative of } \\
\text { air quality for a area at least } 100 \mathrm{~km}^{2} \text { or an entire zone or agglomeration, } \\
\text { whichever is lower. }\end{array}$ \\
\hline $\begin{array}{l}\text { Limit } \\
\text { values }\end{array}$ & $\begin{array}{l}200 \mu \mathrm{\mu g} / \mathrm{m}^{3} \mathrm{NO}_{2} \text { - hourly limit value for protection of human health } \\
40 \mu \mathrm{g} / \mathrm{m}^{3} \mathrm{NO}_{2} \text { - annual limit value for protection of human health }\end{array}$ \\
\hline $\begin{array}{l}\text { Critical } \\
\text { level }\end{array}$ & $30 \mu \mathrm{g} / \mathrm{m}^{3} \mathrm{NO}_{\mathrm{x}}$ - annual critical level for vegetation protection \\
\hline
\end{tabular}

The values recorded in both areas analyzed can be influenced by road traffic or different sources of pollution occurred at a time near the test van.

\section{CONCLUSIONS}

Measurements made with a test van equipped with ozone analyzers and nitrogen oxides on indicators of air quality in the area of high voltage power lines influence $(>110 \mathrm{kV})$ led to the following conclusions: 
$>$ high voltage overhead power lines have an impact on air quality caused by emissions of pollutants substance due to the electrical discharges, as a result of Corona effect;

$>$ the additional intake of pollutants substance in the area of high voltage overhead power lines was revealed by measuring of peak ozone concentrations by $13 \%$ and of maximum concentrations of nitrogen oxides by $30 \%$ higher compared with measurements of pollutants substance concentrations performed outside the area of high voltage overhead power lines influence;

measurements were performed in the following weather conditions: air temperature ranged from $25.7{ }^{\circ} \mathrm{C}$ during the day to $18.3{ }^{\circ} \mathrm{C}$ at night, humidity ranged around 25\% (the high humidity potentiates electrical discharges due to effect Corona) and the wind speed had an average value of $0.65 \mathrm{~m} / \mathrm{s}$;

$>$ the recorded values of the parameters studied, ozone and nitrogen oxides concentrations do not exceed the limits laid down in Law 104/2011 for the protection of human health, they are much lower than these;

$>$ to verify compliance of the target values on vegetation protection are needed campaigns of measurements during April-September between 8.00 and 20.00;

$>$ concentrations of nitrogen oxides can be influenced and by other sources of pollution such as road transportation;

\section{REFERENCES}

1. Vaida et al (2008), Ozone concentration variations near high-voltage transmission lines, Journal of Environmental Engineering and Landscape Management, p. 28-35.

2. Vatră, F. (2011), Reducerea pierderilor tehnice în ret impune trecerea la 3 si 4 conductoare pe faza în cazul lea de $400 \mathrm{kv}$ noi sau retehnologizate, Conferinţa Naţionala şi Expoziţia de Energetică Sinaia, 26-28 Octombrie 2011.

3. *** (2011), Legea $n r$. 104/2011, privind calitatea aerului inconjurator, Monitorul Oficial nr. 452 din 28 iunie 2011. 